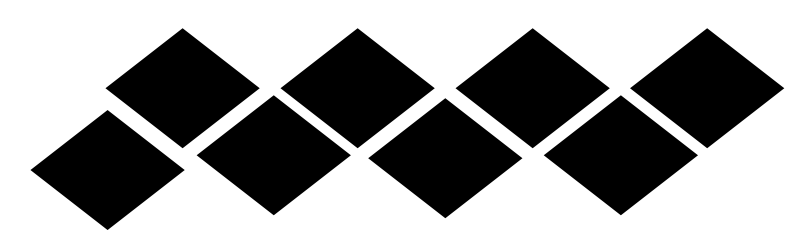

\title{
Palestine in Geography and Fiction: An Interdisciplinary Perspective
}

\author{
Dr. Naeema Alhosani \\ Chair of the Department of Geography and Urban \\ Sustainability \\ UAE University \\ DOI: 10.21608/qarts.2021.54573.1024

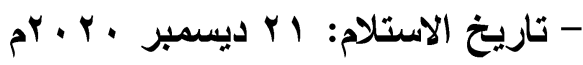

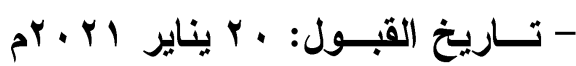

مجلة كلية الاداب بقتا - جامعة جنوب الوادي - العدد 52 (الجز \& الأول) لسنة 2021

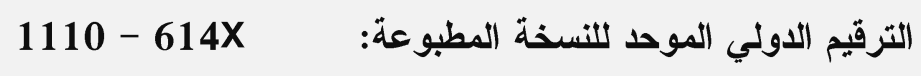

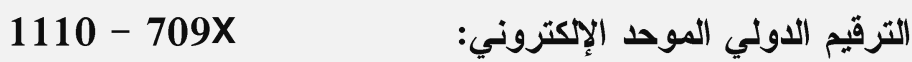

https://qarts.journals.ekb.eg موقع المجلة الاكتروني: 


\title{
Palestine in Geography and Fiction: An Interdisciplinary Perspective
}

\author{
Dr. Naeema Alhosani
}

\section{Chair of the Department of Geography and Urban Sustainability -UAE University}

\begin{abstract}
:
Using critical cartography studies as theoretical basis and argumentative entry, this paper examines the role played by mapmaking in essentializing the Palestinian-Israeli conflict, expanding the gap between the two peoples and maintaining the current dilemma in the Middle East. The paper also draws on political/historical data and fictional narratives written by the Palestinian writer Ghassan Kanafani particularly his seminal novel Returning to Haifa to demonstrate that mapping and cartography are manipulated to achieve dubious political and military purposes. The argument in the paper emphasizes that imperial cartography leads to the mapping production of Palestine as a territorial space of ownership and control by non-Palestinian invaders. In his response to the colonial mapping of Palestine, which aimed to eliminate the country's Arabi identity, Kanafani provides in his fiction alternative cartographies of Palestine to subvert the colonial mapping of his homeland. In other words, Kanafani attempted to reclaim his indigenous territory or part of it through literary maps drawn in his novel discussed in the paper ${ }^{1}$.
\end{abstract}

1 The author of the paper emphasizes that all the arguments related to the changing maps of Palestine reflect the views of their authors in the original 


\section{Introduction:}

Historically, critical cartography emerged during the late 1980s and early 1990s in opposition to the hegemonic tradition of mapmaking. Maps according to Rhiannon Firth are not impartial mechanisms but rather strategic weapons that signify power ${ }^{1}$. For him, critical cartography shows that maps like other texts such as the written word, images or film are not neutral. Maps reflect and perpetuate relations of power, more often in the interests of dominant groups. (Firth 2014: 156). In a recent study, Jeremy Crampton and John Krygier explore the function of critical cartography suggesting that it challenges academic cartography by linking geographic knowledge with power, and thus is political. (Crampton-Krygier 2010: 11). In a similar context, Firth argues that maps embody power relations illustrating that the history of mapping provides evidence that maps are intricately tied up in nineteenth century colonialism and imperialism. On this basis, cartographers drew boundaries that separate people and resources. In another article, John Krygier demonstrates that critical cartography is an umbrella term that refers to discourses about and approaches to the meanings of maps and how maps and the systems for creating them fit into social, cultural, and technical processes.

Krygier proceeds to confirm that critical cartography is an umbrella term that refers to discourses about and approaches to the meanings of maps. Thereupon, critical cartography engages theoretical critique of the social relevance, politics and ethics of mapping. By emphasizing the social aspects of mapping, critical cartography has triggered multiple mapping discourses which throw doubts on the objectivity in spatial representation, the processual nature of map production and interpretation, and participatory methods that question the purportedly objective, neutral views of institutional and state cartographers (Krygier 2019:25). In the same vein, critical cartography challenges professional cartography by situating the map as a discourse of power/knowledge undermining the map as neutral scientific document according to Foucault ${ }^{2}$. Similarly, Derek Gregory acknowledges that, within the discipline of geography, there exists a 
cartographic anxiety about the map's complicity in imperial/colonial power $^{3}$ and the chronic persistence of this relation in present assumptions about cartography ${ }^{4}$.

Unequivocally, the map is a medium for conceptualizing space and mapping may reflect the intersections of space and power. Subsequently, cartography produces space as an object for ownership and control, and, in the process, renders people's lives invisible in their role in the production of space ${ }^{6}$. This trend occurred under colonialism which attempted to produce a "Palestine without Palestinians". Since our perspective of space is bound to the politics, we adopt according to Massey $^{7}$, then the map's significant role in the Palestinian-Israeli dispute makes cartography itself a question worthy of interrogation. Since all places are not territories because territory is linked with power, it is significant to differentiate between a place as territory and other types of places ${ }^{8}$. On this basis, the map becomes a conceptual terrain and alternative or imaginative mappings provide other terrains.

During the nineteenth-century when the Ottomans were in a state of decline, the crumbling empire opened its borders to western travelers. Many of these new visitors were religious scholars who advocated a literal interpretation of the Old Testament and struggled to emphasize Biblical events throughout scientific accuracy. Accordingly, their maps became instruments for imperial allegations to the ownership of Palestine (the Holy Land) ${ }^{9}$.These nineteenth-century cartographic practices removed the indigenous Palestinians from their land and helped engender the premise that Palestine was a country without people prior to the Zionist settlement at the turn of the century.

In response, Palestinians created Counter-maps to underline their presence. Counter-maps are effective in disrupting truth claims but are interesting in themselves for their ability to engender notions that non-state actors can make competing and equally powerful maps as Palestinian scholars and artists have done in recent years ${ }^{10}$. Explicitly, the mapping of Palestine was impacted by what Antonio Gramsci calls "hegemony" which focuses upon how power relations become taken

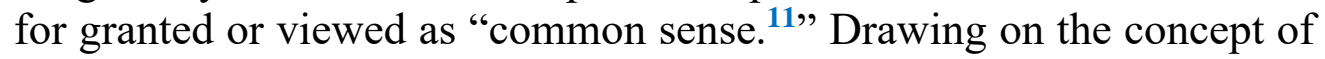
hegemony, Nabil Matar argues that sixteenth-century Renaissance cartography of the "Holy Land" serves as an important starting point to the Question of Palestine (Matar1999:141). 


\section{Mapping Palestine: Cartographic Perspective:}

Categorically, the evolvement of nation-states is attributed to the emergence of the map, which is manipulated as an ideological mechanism to bring the nation-state into existence according to Pickles $^{12}$. Ironically, the Palestinian political negotiators participating with their Israeli counterparts in the Oslo accord in the 1990s advocated cartography, or professional map-making as a strategy of independence, which unfortunately limits both space (the occupied territories) and power (the exclusive realm of the Palestinian authority) Nevertheless, the provisions of the Oslo accord were not realized in reality and Palestinian voices were muted in world media. Moreover, the rights of return for more than seven million Palestinian refugees were denied in Oslo.

The post-Oslo accord era witnessed the evolvement of a new movement which attempted to make a case for the return of refugees by collecting maps, narratives and photographs of a pre-Israel Palestine. However, the Palestinian writer Ghassan Kanafani (prior to Oslo) started this trend in fiction in the aftermath of the 1948 war and the occupation of most of the Palestinian territories. Kanafani belongs to a generation of writers who witnessed the loss of their country and the rejection of their rights by international institutions, which opposed the establishment of an independent Palestinian state. Undoubtedly, these institutions refused to acknowledge the existence of a Palestinian map. Observing the abandonment of the Arab existence in Palestine in western history and cartography, Kanafani provided counter-maps of Palestine in his fiction to refute arguments of the land's emptiness before Zionist immigration. Though the Arabs conquered Palestine in 634 A.D. their existence was barely mentioned in western annals after thirteen centuries of physical presence in the region.

Historically, the first map of Palestine ${ }^{13}$ was created by the cartographers of France, an ex-colonial power. During the colonial reign of Napoleon Bonaparte, the French in 1801 created a historical/geographical encyclopedia (Description of Egypt) delineating the Eastern Mediterranean. It contains cartographic information describing the coastal area region extending from Al-Arish to Saida (Sidon), which becomes the first map of Palestine according to Gavis. ${ }^{14}$ In details, the map of Palestine, created by the French, includes the 
following: Al-Arish (currently located in northern Sinai -Egypt), Gaza (currently in the Palestinian territory), Jerusalem, Jaffa, Caesarea, ancient port south of Haifa and Nazareth, a historic town in lower Galilee (currently all these places are part of the map of Israel). The map of Palestine also includes the entire region that is currently known as Jordan in addition to both Tyre (Sour) and Sidon (Saida) located at southern Lebanon).

Although the first official map was created by French cartographer during the reign of Bonaparte, other western hegemonic powers were interested in Palestine (the Holy Land) since the sixteenth century for religious purposes. Drawing on the argument of Nabil Matar, who reveals that the "Question of Palestine" 15 was originated cartographically in the sixteenth-century before it was disseminated politically in the nineteenth, it is clear that the concept of pilgrimage to "the Holy Land" appeared after the Protestant Reformation in the West when Europeans map Palestine as a homogenous biblical space that should be purified of its native (mostly Muslim) communities.

In the first instance, the European determination in the sixteenthcentury to control Palestine was triggered by religious activities of historical and biblical purposes. In their religious endeavor to reach Palestine, the Europeans created maps of the Holy Land which turn into mechanisms for colonial hegemony in the nineteenth-century. In their pursuit to map the Holy Land, the Europeans, according to Silberman ${ }^{16}$, re-created Palestine as a biblical vestige and territorial site for western colonial sovereignty. In both conditions, the Palestinian people are completely ignored or confined to the colonial ghetto. In this sense, cartography, a neutral science, is transformed into an oppressive apparatus displacing the Palestinians.

Confirming Matar's previous suggestion that the map of Palestine was basically founded during the sixteenth-century, it is obvious that in Renaissance cartography Palestine (the Holy Land) was depicted in Theatrum Orbis Terrarum or the Theater of the World by Abraham Ortelius. The manuscript, published in 1570, was considered the Atlas of the Renaissance ${ }^{17}$. While the Atlas, from an ultimately geographical perspective, provides details about navigation routes, travels locations commerce destinations and harbors crucial for sailors and merchants, its delineation of the map of Palestine (the holy land) 
was heavily impacted by biblical conceptions. The map is neither navigational nor topographical according to Matar. Whereas most of the Atlas views sixteenth-century trading routes and commercial harbors, the map of Palestine describes the passage the Jews followed when they escaped the tyranny of Pharaonic Egypt into the Promised Land ${ }^{18}$. Surprisingly, the map of Palestine in the $16^{\text {th }}$ century Atlas has no relevance to the real map of historical Palestine. Palestine in this map includes the Red Sea on the Egyptian borders, which witnessed the crossing of the Jews fleeing Egypt during the exodus, then the wilderness where the Jews resided before they tramped over the River Jordan on their way to enter Canaan, the Promised Land.

Matar argues that while the author of the $16^{\text {th }}$ century Atlas, A. Ortelius, sold maps to his customers which provided information about "their global commerce, he had no qualms about presenting Palestine as meta-Palestine, a holy land without contemporary accuracy". Matar proceeds to state that in the sixteenth-century "Palestine had been mapped as far as biblical times and therefore its cartographic borders had been finalized by divine authority" (Matar 2011: 63). Thereupon, Palestine was delineated as a legendary destination processed by a cartography integrated into western biblical sources, which is not able to separate geographical facts from religious mythology.

Palestine also appeared in western maps during the crusade era and after the Napoleon's invasion of the region in 1798. Robinson and Smith started their exploration of Palestine after France's three-year occupation of Egypt and invasion of Palestine. They observed that the Ottoman Empire was on the verge of collapse. The strong army of Mohamed Ali, the governor of Egypt, was able to take Palestine from Istanbul in 1831as a result of French military support, but Ali forced to withdraw from Palestine in 1840 due to the British interference on the side of the Ottomans. This shows that Palestine was caught up in the crossfire of battling European colonial forces and their local proxies.

In the nineteenth-century, Edward Robinson and Eli Smith created a map for Palestine, which appeared in his narrative travel book titled Biblical Researches in Palestine and the Adjacent Regions. Published in 1841, the book was addressed to the English-speaking world according to Long (Long 2002: 133). Instead of focusing on 
geographical data, the book includes details about the miracles of prophet Moses as he parted the Red Sea to allow God's Chosen People to cross on dry ground, then God directed Moses to close the waters that they may engulf the Pharaoh's chariots and horsemen in pursuit ${ }^{19}$. A similar narrative was narrated in the Quran: Then We (Allah) told Moses by inspiration: "Strike the sea with thy rod/ So, it divided, and each separate part became like the huge, firm mass of a mountain" ${ }^{20}$. According to Muslim scholars, the Red Sea was divided into twelve paths, one for each of the tribes of the Israelis, the followers of Moses. Furthermore, Robinson and Smith, in their travel accounts, considered the study of the historical geography of Palestine as an initial attempt to explore "the treasures of Biblical Geography and History still remaining in the Holy Land; treasures which have lain for ages unexplored, and had become so covered with the dust and rubbish of many centuries, that their very existence was forgotten" 21 .

The mapping of Palestine in the nineteenth-century was impacted by biblical tales about the invasion of the holy land. In the Book of Joshua, there is a narrative about Joshua's reception of God's orders to invade Palestine after the death of Moses. God told Joshua to lead the Israelite army across the Jordan river into the holy land (Canaan) $^{22}$. According to the Jewish bible, the children of Israel are thus to receive "Every place that the sole of your foot shall tread upon" 23 . A bloody narrative from the bible unfolds that the Israelites must annihilate the indigenous Canaanites city by city according to God's orders. After their victory, Canaan will be divided among the twelve tribes of Israel. Another narrative shows that according to God's commands the indigenous people of Canaan should be enslaved rather than demolished and slaughtered. In both narratives, the Promised Land's boundaries are determined to be from $\operatorname{Dan}^{24}$ to Beer Sheba ${ }^{25}$. Apparently, the nineteenth-century cartographic obsession with Palestine was profoundly influenced by "Biblical antiquities served as a subtle means of Western penetration and inter-European competition; (Silberman 1982: 4).

In the middle of the nineteenth-century, "Dan and Beer Sheba", the biblical borders of Palestine are inserted in the map of Palestine once more at the hands of the London-Based Palestine Exploration Fund, that came into existence "at a time when Britain was struggling 
to define its colonial purpose and secure its imperial frontiers" according to Moscrop ${ }^{26}$. Apparently, the modern borders of Palestine were inspired by biblical cartography endorsed by western surveys of the country. Many modern European cartographers mapped Jerusalem, the Dead Sea, and other religiously oriented locations producing a bounded Holy Land map that extends from Dan to Beer Sheba.

\section{The Changing Map of Palestine:}

Apparently, cartography has immensely participated in the displacement of Palestinians since the nineteenth-century. During an era of colonial conquest, the imperialist powers particularly the British government conspired with fanatic protestants to marginalize the Palestinians using maps and cartography as weapons. Accordingly, the borders of Palestine were radically transformed in the aftermath of British Mandate following the decline of the Ottomans in 1923. Unfortunately, the British took the side of the Zionists in Europe and changed the map of Palestine to satisfy the ambitions of the Zionist movement. After the map of Palestine was altered and the borders were metamorphosed, the British surrendered the Palestinian issue to the United Nations.

Historically, Palestine became a British colony (zone of influence) in the early twentieth-century. According to the clandestine Sykes-Picot Agreement (1916), Palestine fell under British mandate. The British occupation of Palestine fulfilled commercial purposes for England. The Palestinian harbors of at Haifa and Akka were used to export oil coming from Iraq throughout pipelines reaching the Mediterranean. Under occupation, Palestine and its native population fell prey to the British apocalyptic vision. Many British protestant movements believed in the Second Coming of Christ $^{27}$ foreshadowing the end of this epoch. According to this biblical vision, Christ will return to Jerusalem and the Jews will return "to the land of their fathers and their immediate conversion, or, alternatively, their recognition of the Messianic claims of the Christian Savior" (Perry 2003: 3). The evacuation of Palestine from its indigenous people is a pre-text to the fulfillment of the Messianic prophecy. The London Society for Promoting Christianity Amongst the Jews (the London Jews Society), a Christian Zionist organization established in the beginning of the 
nineteenth century, was among the protestant movements mentioned above.

Some protestant movements considered the Jews as an instrument in the process of accelerating the return of the Messiah (Christ) therefore, they support their return to Palestine for religious reasons. Others were active in assisting Jewish immigration to Palestine as a means of atonement for the sins committed by the Church against the Jews throughout centuries. In 1917, after the troops of General Allenby occupied Jerusalem, the evangelical British prime minister, Lloyd George, urged Arthur Balfour, the foreign secretary, to declare the foundation of a national homeland for the Jews in Palestine. After the end of WWI and at the Paris peace conference (1919), the British prime minister invited a delegation from the Zionist Organization to suggest the post-war official borders of Palestine. During the Conference, the evangelical British prime minister informed the French that the British forces would control Palestine "as defined in accordance with its ancient boundaries of Dan to Beer Sheba" 28 and the French accepted the declaration after investigating the biblical maps of Palestine. Surprisingly, the Zionist Organization representatives were hesitant. They wanted to expand the northern boundaries of Palestine eastwards in order to have all of Mount Hermon's waters inside Palestine. They argue that their emerging state needs more water resources because agriculture will be the backbone of the country's economy. The French did not accept the Jewish request and consequently the biblical borders of Palestine were approved by all parties. In 1923, the borders of Mandate Palestine, from Dan to Beer Sheba were officially endorsed.

Under the British Mandate of Palestine, cartography played a hegemonic role in the dispossession of the Palestinian people. The map of Palestine was altered after the issuance of the Peel Commission report $^{29}$. After WWII, the Peel Commission had suggested the United Nations' partition of Palestine into two nation-states excluding Jerusalem, which remained an international zone. The U.N. Partition plan exceeded the geographical boundaries authorized by the Peel Committee. In other words, the U.N. map cuts significant parts from the Palestinian territories approved by the Peel Committee. The Israelis were given more land and the Arabs logically rejected the biased 
partition plan. Ironically, the United Nations' partition plan paved the way for the 1948 war. Prior to the 1948 war, the Palestinian map included Jewish settlements scattered across Palestinian cities and towns. Most of the landscape constitutes Palestinian towns and villages, which were largely demolished and eliminated in the future. In fact, the borders of Palestine were radically metamorphosed by the United Nations' 1947 partition plan rejected by the Arabs and resulted into the 1948 war.

The armed conflict, subsequently led to the creation and implementation of the armistice zone between the Arabs and the Israelis in 1949, what was called (the Green Line). In the post-1948 war era, the boundaries of Palestine included the emerging state of Israel recognized by the United Nations. Furthermore, the consequences of the 1967 war impacted the map of Palestine after Israel annexed the entire city of Jerusalem and the West bank towns in addition to Gaza. With the passage of time, the Israelis annexed more Palestinian territories. When the Palestinian leadership started the peace talks with the Israelis in Camp David in 1988, they were negotiating for 22 percent of Palestine (Hanieh 2001: 95).

After the establishment of the state of Israel in 1948, there was no map for Palestine. The only map posted on world-wide sites and recognized by international institutions is the map of Israel. Zionist cartographers created a map of Israel/Palestine reminiscent of the biblical maps of their colonial Christian predecessors. On the new map they changed the Palestinian names of villages, cities and other geographical destinations to abide with the Hebrew names mentioned in Israeli religious sources. All the Arabic names of places and locations that were found on the Palestinian maps drawn by the British during the Mandate were erased and replaced by Hebrew names with biblical oriented shades. In this context, Benvenisti argues that when the Israeli cartographers found Arabic names of geographical or historical or any other location on the maps of Palestine handled to them by the British Mandate authority, they erased the Arabic names adding the Hebrew word (harus) which means "destroyed". (Benvenisti 2000:41). After the foundation of Israeli, Zionist cartographers created nation-state maps which correspond to the biblical maps of antiquity. 
Prior to the 1967 war Israeli map-makers created maps according to the 1949 armistice lines without any mention of the Palestinians. Whereas the map of Palestine disappeared completely after the 1967 war, the map of Israel included the Gaza Strip, the West Bank, East Jerusalem, the Golan Heights, and the Sinai Peninsula. In the post-1967 war era, Israeli cartographers removed the 1949 armistice lines from their maps. For military reasons, the map of Palestine changed with the Zionist settlement project in the Occupied Territories coming into effect. On the new map, "the West Bank" did not exist and was replaced by the biblical "Judea and Samaria" ignoring the existence of the indigenous Palestinian population. Apparently, Israel has used cartography to help legitimize it as a well-established state.

\section{Contesting the Colonial Mapping of Palestine:}

In his response to the Oslo Accord in the early 1990s between the Palestinian Authority representatives and the Israelis, Edward Said lamented the lack of maps in the hands of the Palestinian delegation engaged in the negotiations. Said demonstrated that geography is the art of war but can also be the art of resistance if there is a counter-map and a counter-strategy ${ }^{30}$. The "counter-map" premise or the counternarrative is advocated by Palestinian writers since the early 1950s, particularly Kanafani who delineates a map of Palestine in his novels insisting on using Arabic names of geographical locations, streets, towns, names and other destinations to refute the colonial and orientalist cartography that aimed to undermine the Arabic identity and history of Palestine viewing it as a wasteland or a country without people.

Moreover, western cartography of Palestine aims to justify colonization by depicting the colonial process as a historically inevitable movement of progress toward bringing civilization to the land of the barbarians. Originated in Orientalism and western imperialism the ancient map of Palestine either removes the Palestinian subaltern out of his homeland or conflates him with a status of cultural inferiority and barbarism by assigning him a role which conforms to his image in the colonial taxonomy of inferior races. In other words, cartography was manipulated to silence the Palestinian subaltern or consider him as invisible, or conflate him with a status of cultural decadence and 
backwardness. After the occupation of Palestine by the British forces during WWI, the colonizers immediately used geography to blur facts and distort history by producing a new map of Palestine/Israel. There is no doubt that cartography was largely utilized by the invaders to measure and map the territories they were determined to control ushering into an era of cooperation between colonialism and the science of geography ${ }^{31}$.

In his famous novel Returning to Haifa (1969), Kanafani introduces a narrative which reminds the readers with Haifa when it fell a prey to Zionist attacks during the 1967 war. However, the novel, which emphasizes the Arabic identity of Haifa, humanized the eastern Jews and the indigenous Jewish communities in the city who lived in harmony with their Arab neighbors for centuries prior to the conquest of the Zionists. Kanafani's Returning to Haifa (1969) marks a turning point in Arabic literature after 1948 because the author deploys positive images of the Jews challenging orthodox Arabic narratives. Unlike writers who either romanticize or demonize the Jew, Kanafani underlines human issues of common interest between the two sides of the conflict foreshadowing the political agenda of the novel. In Returning to Haifa, Ghassan Kanafani introduces the Arab-Israeli conflict not only by incorporating Palestinian suffering and displacement, as in traditional Arabic literature, but also through an engagement with the Jewish history of Diaspora and genocide. The Jewish motif, in the novel, has precipitated the emergence of a new pattern of Jewish characters in Arabic literature associated with the nature of the cultural other. The awareness of such a motif which results from an encounter between the Palestinians and the Jews emerged as an outburst of literary consciousness characterizing major Palestinian literature on the conflict.

The novel comprises the journey of the Palestinian protagonist, Said S. who returned to his occupied city (Haifa), many years after its occupation by the Zionists supported by the British in 1948 war. Said was forced to escape the city during war leaving behind his little baby who was later adopted by childless Jewish settlers who lived in his house. Said and his wife came from the occupied territory with permission to visit the city that used to be their habitat and to look for their 
forgotten son. In the novel, Kanafani focused on using the Arabic names of the city's locations and destinations that existed prior to occupation. Said was traveling north, across the plain which was called Ibn Amar twenty years ago: "When he reached the edge of Haifa, approaching by car along the Jerusalem road, had the sensation that something was binding his tongue, compelling him to keep silent, and he felt grief well up inside of him. For one moment he was tempted to turn back, and without even looking at her he knew that his wife had begun to cry silently. Then suddenly came the sound of the sea, exactly the way it used to be. Oh no, the memory did not return to him little by little. Instead, it rained down inside his head the way a stone wall collapses. He told himself that Safiyya, his wife, felt exactly the same, and that was why she was crying" (Kanafani 149) ${ }^{32}$.

The protagonist recalled past memories in a nostalgic manner: "Ever since he left Ramallah that morning he had not stopped talking, nor had she. He spoke to his wife about everything- about the war and about the defeat, about the Mandelbaum Gate, demolished by bulldozers. And about the enemy, who reached the river, then the canal, then the edge of Damascus in a matter of hours" (Kanafani 150). He remembered the bitter memories of the 1948 war "the neighbor who gathered his things and fled, and the three Arab soldiers who fought alone for two days on the hill near Augusta Victoria Hospital, and the men who took off their army uniforms and fought in the streets of Jerusalem, and the peasant who was killed the minute they saw him near the largest hotel in Ramallah. His wife spoke of many other matters. Throughout the entire journey neither of them stopped talking. Now, as they reached the entrance to Haifa, they both fell silent." (151).

When Said reached the city at noon, in June 30, 1967, he heard himself say to his wife, "This is Haifa, Safiyya!" "I know this Haifa, You know, for twenty long years I always imagined that the Mandelbaum Gate would be opened some day, but I never, never imagined that it would be opened from the other side" (150). The Mandelbaum Gate divided Jerusalem into two parts since the British Mandate but after the 1967 war the Jews removed the barrier between the two sides of Jerusalem.

When Said reached the city at noon, in June 30, 1967, he heard 
himself say to his wife, “This is Haifa, Safiyya!" "I know this Haifa, you know, for twenty long years I always imagined that the Mandelbaum Gate would be opened some day, but I never, never imagined that it would be opened from the other side" (150). The Mandelbaum Gate divided Jerusalem into two parts since the British Mandate but after the 1967 war the Jews removed the barrier between the two sides of Jerusalem: "They opened the border as soon as they completed the occupation, suddenly and immediately. That has never happened in any war in history. You know the terrible thing that happened in April 1948, so now, why this? Just for our sakes alone? ${ }^{3}$ No! This is part of the war. They're saying to us, 'Help yourselves, look and see how much better we are than you, how much more developed. You should accept being our servants" (151).

The protagonist was still obsessed with the 1948 war memories regardless of the time span: As he drove the car through the center of Haifa, the smell of war was still strong enough to make the city seem to him dark and excited and agitated, the faces harsh and savage. After a little while he realized that he was driving the car through Haifa with the feeling that nothing in the streets had changed" (151). Said started to remember the names of the city destinations prior to the conquest: "The names began to rain down inside his head as though a great layer of dust had been shaken off them: Wadi Nisnas, King Faisal Street, Hanatir Square, Halisa, Hadar." (152). Some of the names are associated with the Jewish districts in the city.

Said describes the city during the war emphasizing the Arabic names of the city's surroundings: "Thunder came abruptly from the east, from the heights of Mount Carmel. Mortar shells flew across the city's center, pelting the Arab quarters. The streets of Haifa turned into chaos. Alarm swept through the city as it closed its shops and the windows of its houses. Said He went down the side streets in an attempt to cross the road to Halisa, where he lived, but the fighting had already spread. As he quickened his pace, he knew for certain that he had to avoid the high sections of town adjoining Herzl Street, where the Jews had been headquartered from the beginning. The names became tangled up in his head: Halisa, Wadi Rushmiyya, the Burj, the Old City, Wadi Nisnas" (153). 
While delineating the battle, Said refers to the interference of the British in the battle: "The explosions intensified. Even though he was far enough away from the site of the shooting he could still make out British soldiers who were boarding up some windows and opening others. Somehow, he found himself in the Old City and from there he raced with a strength he didn't know he possessed toward South Stanton Street. And then he knew he was less than two hundred meters away from Halul Street, and he began to catch the scent of the sea" (154).

Despite the passage of time, Sais is still able to view the geography of the embattled town: "He didn't know how many hours had passed as he rushed from street to street, but it was clear that he was being propelled toward the port. All the side streets leading off the main road were closed. He kept plunging down side streets trying to get to his house, but he was always driven back, sometimes by rifle muzzles, sometimes by bayonets. People were pouring from the side streets into the main street leading down to the port-men, women and children, empty-handed or carrying a few small possessions, crying or being floated along in a paralyzed silence in the midst of the clamor and confusion" (155).

Said, the protagonist recalled the final moments in Haifa before he was thrown into a boat in the sea to start his journey as a refugee: "He went through the Iron Gate to the port where British soldiers were restraining people. From the gate he could see masses of people tumbling one over the other, falling into the small rowboats waiting near the wharf Said forged ahead, using his shoulders and forearms, his thighs, even his head. The current carried him a few steps backward, but he pushed on wildly like some hunted creature hopelessly trying to forge a path through a thick tangle of undergrowth. Above him the smoke and the wailing of bombs and hail of gunfire fused with the screams, the footsteps, the sea's pounding, and the sound of oars slapping the surface of the waves" (155).

Then, Said experienced a moment of contemplation: "All the way from Ramallah to Jerusalem to Haifa he talked about everything, 
without stopping for a moment. But when he reached the entrance to Bat Gallim, silence bound his tongue. Here he was in Halisa, listening to the sound his car wheels always made when they turned. Twenty years of absence had dwindled away and suddenly, incredibly, things were right back to where they had been, despite all reason and logic" (156). He recalled how he decided to come to Haifa: "A week ago, in their house in Ramallah, Safiyya had said to him: "They're going everywhere now. Why don't we go to Haifa?". He replied: "Let's go to Haifa tomorrow. At least take a look. Maybe we can pass near our house. I think they're going to issue an order prohibiting it soon. Their calculations were wrong." $\mathrm{He}$ was quiet for a moment. He wasn't sure whether he wanted to change the subject, but "Let's go to Haifa tomorrow. At least take a look. Maybe we can pass near our house. I think they're going to issue an order prohibiting it soon. He heard himself continue: "In Jerusalem and Nablus and here people talk every day about their visits to Jaffa, Acre, Tel Aviv, Haifa, Safad, towns in Galilee and in Muthallath" (157).

Throughout the journey, Said and his wife talked about everything except their son Khaldun. Finally, nearing Bat Gallim, they fell silent: "Here they were, gazing silently at the road they both knew so well, its memory stuck fast in their heads like part of their very flesh and bones. As he used to do twenty years before, he slowed the car down to its lowest gear before reaching the curve that he knew concealed a difficult rocky surface behind it. He turned the car the way he always did and climbed the slope, watching out for the exact spot on the narrowing road" (159).

When they reached their house in Haifa, they found a Jewish family there. The house was inhabited by a childless couple Iphrat Koshen and his wife Miriam who rescued his baby and adopted him as their son naming him Dov. The Jewish family told Said and his wife what happened: "In April 21, 1948, when Said S. left Haifa on a British boat, pushed aboard with his wife, to be cast off an hour later on the empty shore of Acre, and Thursday, April 29, 1948, when a member of the Haganah, accompanied by a man who looked like a chicken, opened the door of Said S.'s house in Halisa. With that opening, the way was cleared for Iphrat Koshen and his wife, who 
had both come from Poland, to enter what from then on became their house, rented from the Bureau of Absentee Property in Haifa. Iphrat Koshen reached Haifa via Milan early in the month of March under the auspices of the Jewish Agency.' He had left Warsaw with a small convoy of people in early November of 1947. He lived in a temporary residence on the outskirts of the Italian port, which at the time was fraught with unaccustomed activity. At the beginning of March, he was transferred by ship with some of the other men and women to Haifa" (165).

Underlining the indigenous geographical locations whether Arabic or Jewish, Kanafani allows Iphrat Koshen to narrate his journey after reaching Palestine and settled in the Jewish district in Haifa (Hada): "At Hadar he lived in a small room in a building choked with people.

Iphrat Koshen soon realized that most of the rooms in the building were packed with new emigres waiting for eventual transfer to some other place. In truth, he believed that when things calmed down, he'd go to live in a quiet house in the country at the foot of some hill in Galilee. He'd read Thieves in the Night by Arthur Koestler ${ }^{15}$ while in Milan; a man who came from England to oversee the emigration operation had lent it to him. This man had lived for a while on the very hill in Galilee that Koestler used as the background for his novel. Actually, not much was known about Palestine at that time. In truth, he believed that when things calmed down, he'd go to live in a quiet house in the country at the foot of some hill in Galilee. He'd read Thieves in the Night by Arthur Koestler ${ }^{15}$ while in Milan; a man who came from England to oversee the emigration operation had lent it to him. This man had lived for a while on the very hill in Galilee that Koestler used as the background for his novel. Actually, not much was known about Palestine at that time" 169).

Kanafani gives Iphrat a space in the text to react to Said's version of the war in Haifa: "Only on Friday morning, April 23, could he tell for sure that it was all over in Haifa; the Haganah controlled the entire area. Colonel Moshe Karmatil was directing three battalions in Hadar Ha-Carmel and the business district. One of the battalions was to sweep through Halisa, the bridge and Wadi Rushmiyya, toward the port" (170). Moreover, Iphrat narrated his 
own story after listening to Said's narrative about his expulsion from the town. Said and his wife were not able to take their son who was left alone in their house due to the intensity of the battle: "In Thursday evening, April 22, 1948, Tura Zonshtein, the divorced woman who lived with her small son on the third floor, right above Said S., heard a sound coming from the second floor of a baby weakly crying. Thursday, the $29 \mathrm{th}^{23}$ of April, 1948, was the day when Iphrat Koshen and his wife Miriam, accompanied by the chicken-faced man from the Jewish Agency carrying a five-monthold baby, entered the house of Said S. in Halisa" (171).

During the conversation, Said and his wife were informed that their son became a soldier in the Israeli army and was converted to Judaism. Afterwards, Dove returned in his military suit and in the confrontation with his biological parents, he blamed them for leaving him behind and abandoning him as a child. He admitted that his real parents are the Jewish couple and he insisted on staying with them as a Jew faithful to the state of Israel. Through the character of Dov and his encounter with his parents, Kanafani throws light on many political issues symbolically which are not the topics of this paper. However, the author castigates the Palestinian leadership who neglected the Palestinian cause leaving Palestine to the Jews and their allies to create and recreate the map of Palestine to fulfill their colonial ambitions. At the end of the novel the author insists on the Arabic identity of Palestine by referring to streets in Haifa that had Arabic names: "The road outside was nearly empty. He headed for the car and let it coast noiselessly to the foot of the slope. Only at the bend did he start the engine and head for King Faisal Street" (188).

\section{Conclusion:}

In the context of the above-mentioned argument, this paper explored the Palestinian question from a cartographic perspective merging political geography with fictional narratives in order to underline the crippling impact of biblical and colonial mapping on the current destiny of the Palestinian people. The paper started with a survey of the mapping history of the Palestinian territories since ancient times until the Oslo agreements in the 1990's in order to emphasize that the map of Palestine was historically subjected to a systematic process of intended restructuring and modifications leading to the exodus and 
immigration of the native inhabitants of the land and the transformation of the Palestinians into a nation of refugees since 1948.

The issue of immigration and the tragedy of the Palestinian refugees resulting from a conspiracy of colonial re-mapping of their country was illustrated through tracking the cartographic trajectories of Palestine back to ancient times. The paper also revealed the reaction of the Palestinian novelist, Kanafani toward the distortion of the map of his country by delineating a literary map of Palestine on the eve of the 1948 war, a map which emphasized the co-existence between Arab Palestinians and eastern Jews in addition to other ethnic minorities in the land of Palestine prior to the arrival of the European Zionists. On one hand, the paper argues that Kanafani's Returning to Haifa epitomizes the consequences of colonial mapping reflecting the crippling effect of the partition of Palestine on the psyche of the Palestinians who were forced to immigrate to surrounding Arab countries seeking potential sources of income for their families and leaving behind them a country that did not have recognized political borders and did not exist on official maps. In order to clarify the preceding points, the argument of the paper uses critical cartography studies as a point of departure followed by a textual analysis of Kanafani’s Returning to Haifa.

Moreover, In Returning to Haifa, Kanafani revealed that, the map of Palestine was victimized by domineering imperialistic forces that occupied the country for decades. Kanafani also illustrates that both Arabs and Jews were historically devastated by different types of colonization whether the colonizers came from the West or the East. The invaders were keen on disintegrating the multi-ethnic Palestinian populations and changing the map of Palestine on perpetual and regular basis. Due to these colonial aggressions, parts of historical Palestine were given to other countries such as Jordan, Lebanon and Syria. Kanafani also emphasizes the historical rights of the Jews and the Arabs in Palestine. In Returning to Haifa, the immigrant Jewish couple, Miriam and Iphrat Koshen, victims of the holocaust, saved the Palestinian child from imminent death after his parents abandoned him and escaped from the city of Haifa. The Jewish couple brought up the child as a Jew named Dov who became a soldier in the Israeli army. When Dov confronted his biological Arab parents, he refused to return 
with them to Ramallah and preferred to continue his life as an Israeli. Kanafani signifies here that the Jews who stayed in the country and did not flee and the Jews who came from Diaspora / the holocaust survivors deserve to have Palestine as their homeland. The journey of the novel's protagonist, Said, S. the father of the Khaldun/Dov forth and back from Ramallah to Haifa provided him with more insights about the JewishArab existence in Palestine and illuminates many issues for him and his wife. Apparently, Kanafani aims to humanize the Jews by showing sympathy toward the victims of the holocaust whereas he denounces all kinds of violence. Kanafani symbolically castigates the violence committed by all colonial powers (France, England and Turkey) who occupied Palestine and changed its map several times ignoring the rights of the indigenous population including the Arabs and the Jews.

\section{Notes:}

1 Firth, Rhiannon (15 April 2015). Critical Cartography. The Occupied Times of London (27). Retrieved 16 February 2018.

${ }^{2}$ Foucault, Michel. Power/Knowledge: Selected Interviews and Other Writings, 1972-197: New York: Pantheon, 1980.

${ }^{3}$ Gregory, Derek. Geographical Imaginations. Oxford: Wiley-Blackwell, 1998.

4 Sparke, Matthew. A Map that Roared and an Original Atlas: Canada, Cartography, and the Narration of Nation. Annals of the Association of American Geographers (1998) 88: 463-495.

${ }^{5}$ Crampton, Jeremy. The Political Mapping of Cyberspace. Chicago: University of Chicago Press, 2004.

${ }^{6}$ Lefebvre, Henri. The Production of Space. Oxford: Wiley-Blackwell, 1991.

${ }^{7}$ Massey, Doreen. For Space. London: Sage, 2005.

${ }^{8}$ Sack, Robert David. Human territoriality: its theory and history. New York: Cambridge University Press, 1986. 
${ }^{9}$ Long, Burke O. Imagining the Holy Land: Maps, Models, and Fantasy Travels. Bloomington:

Indiana University Press, 2002.

${ }^{10}$ Wood, Denis. The Power of Maps: New York: The Guilford Press, 1992.

11 Gramsci, Antonio. Selections from the Prison Notebooks. New York: International Publishers Co. 1971.

12 Pickles, John. A History of Spaces: Cartographic Reason, Mapping and the Geo-Coded World: London: Routledge, 2003.

${ }^{13}$ For more details about the changes in the map of Palestine throughout history see the six maps in the appendix at the end of the paper.

${ }^{14}$ Gavish, Dov. A Survey of Palestine under the British Mandate, 1920-1948. London:

Routledge, 2005.

${ }^{15}$ Matar, Nabil. Renaissance Cartography and the Question of Palestine (1999).

${ }^{16}$ Silberman, Neil Asher. Digging for God and Country: Exploration, archeology, and the secret struggle for the Holy Land, 1799-1917. New York: Random House, 1982.

${ }^{17}$ For more details on this point, see Linda Elizabeth Quiquivix. The Political Palestine (Diss). Chapel Hill: University of North Carolina, 2012.

${ }^{18}$ Matar, Nabil. Renaissance Cartography and the Question of Palestine (1999).

${ }^{19}$ Exodus 14: 21-30

${ }^{20}$ The Holy Quran- AlShuaraa/the Poets Sura, verse 63.

${ }^{21}$ Robinson, Edward and Eli Smith. Biblical researches in Palestine, and the adjacent regions. Boston: Crocker and Brewster, 1856. P.10.

22 The land known as Canaan was situated in the territory of the southern Levant, which today encompasses Israel, the West Bank and Gaza, Jordan, and the southern portions of Syria and Lebanon.

${ }^{23}$ Joshua 1: 3 
${ }^{24}$ Dan (Mound of the Judge or Tal El Qadi in Arabic) is situated in the area known as the Galilee Panhandle. To the west is the southern part of Mount Lebanon; to the east and north are the Hermon mountains. The name appears in a proverbial expression, 'from Dan to Beersheba,' signifying the whole length of the Promised Land.

25 Judges 20: 1 (Beersheba is located on the northern edge of the Negev desert 115 kilometers south-east of Tel Aviv and 120 kilometers south-west of Jerusalem. The city is located on the main route from the center and north of the country to Eilat in the far south).

${ }^{26}$ Moscrop, John James. Measuring Jerusalem: The Palestine Exploration Fund and British Interests in the Holy Land. London: Leicester University Press, 2000.

27 The Second Coming is a Christian concept regarding the return of Jesus to Earth after his "first coming" and his believed ascension to heaven about two thousand years ago. The belief is based on messianic prophecies found in the canonical gospels and is part of most Christian sects.

28 McTague Jr., John J. Anglo-French Negotiations over the Boundaries of Palestine, 1919-1920. Journal of Palestine Studies (1982) 11:100-112

29 It is a British Royal commission of inquiry chaired by Lord Peel. The commission published a report recommending the partition of Palestine into two states. The report was endorsed by the League of Nations prior to the outburst of the 1948 war.

${ }^{30}$ Said, Edward. Facts, facts, and more facts. in Peace and Its Discontents: Essays on Palestine in the Middle East Peace Process. New York: Vintage, 1996. PP. 2631.

${ }^{31}$ Edney, Matthew. Mapping an Empire: The Geographical Construction of British India. Chicago: University of Chicago Press, 1997.

32 All subsequent citations are quoted from Kanafani Ghassan. Palestine's Children: Returning to Haifa and Other Stories, Ed/Trans. Barbara Harlow and Karen E. Riley. Boulder, Colorado: Lynne Rienner Publishers Inc., 2000. (PP. 149-196). 


\section{Appendix:}

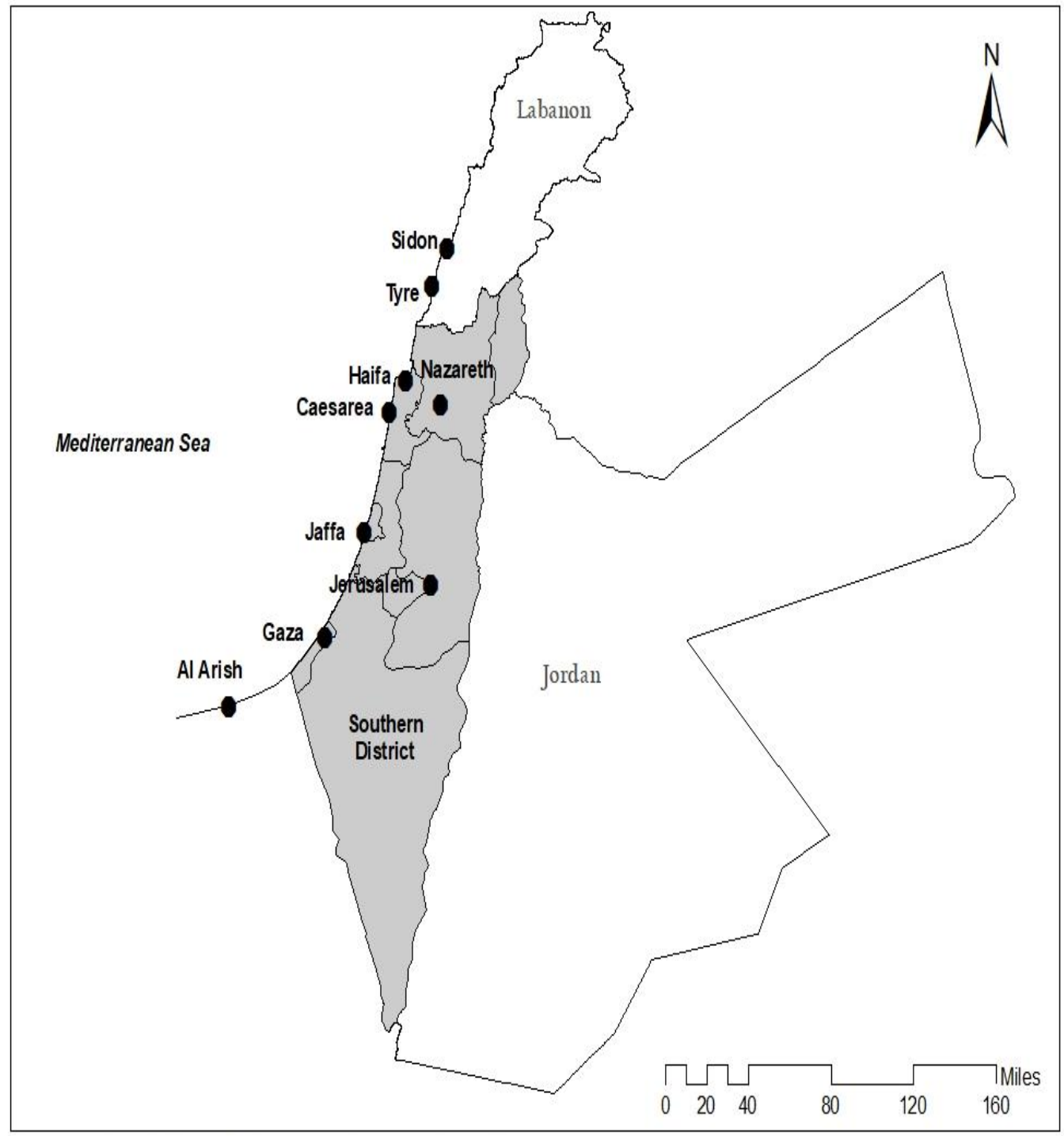

Source:An Ancient Map of Palestine designed and created by the author 


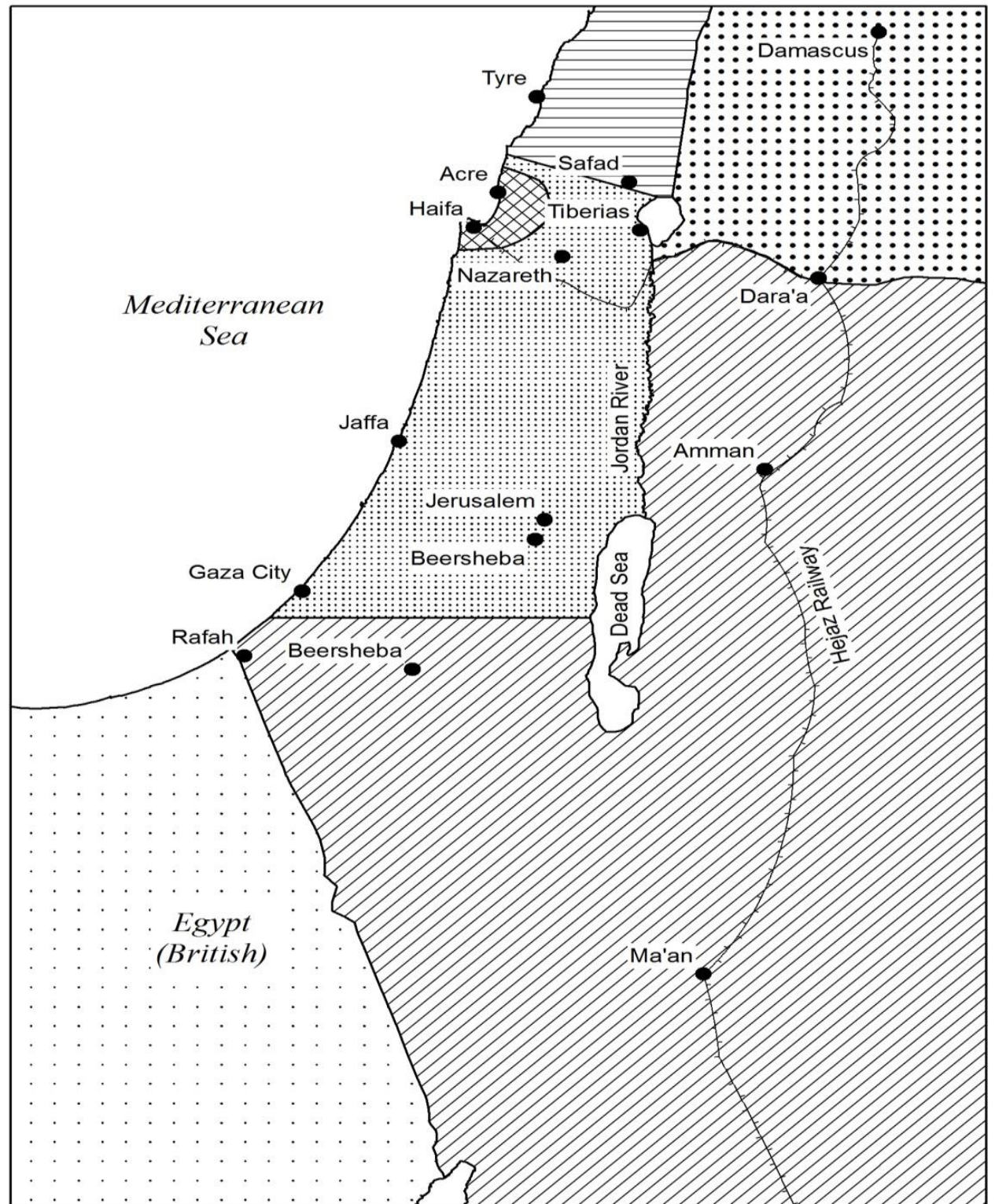

International Area
British

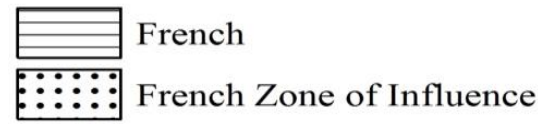

DPritish Zone of Influence

Map of Palestine according to the Sykes-Picot accord 1916 (adapted by the author from Biger, Gideon. The Boundaries of Modern Palestine, 1840-1947. London \& New York: Routledge, 2004.) 


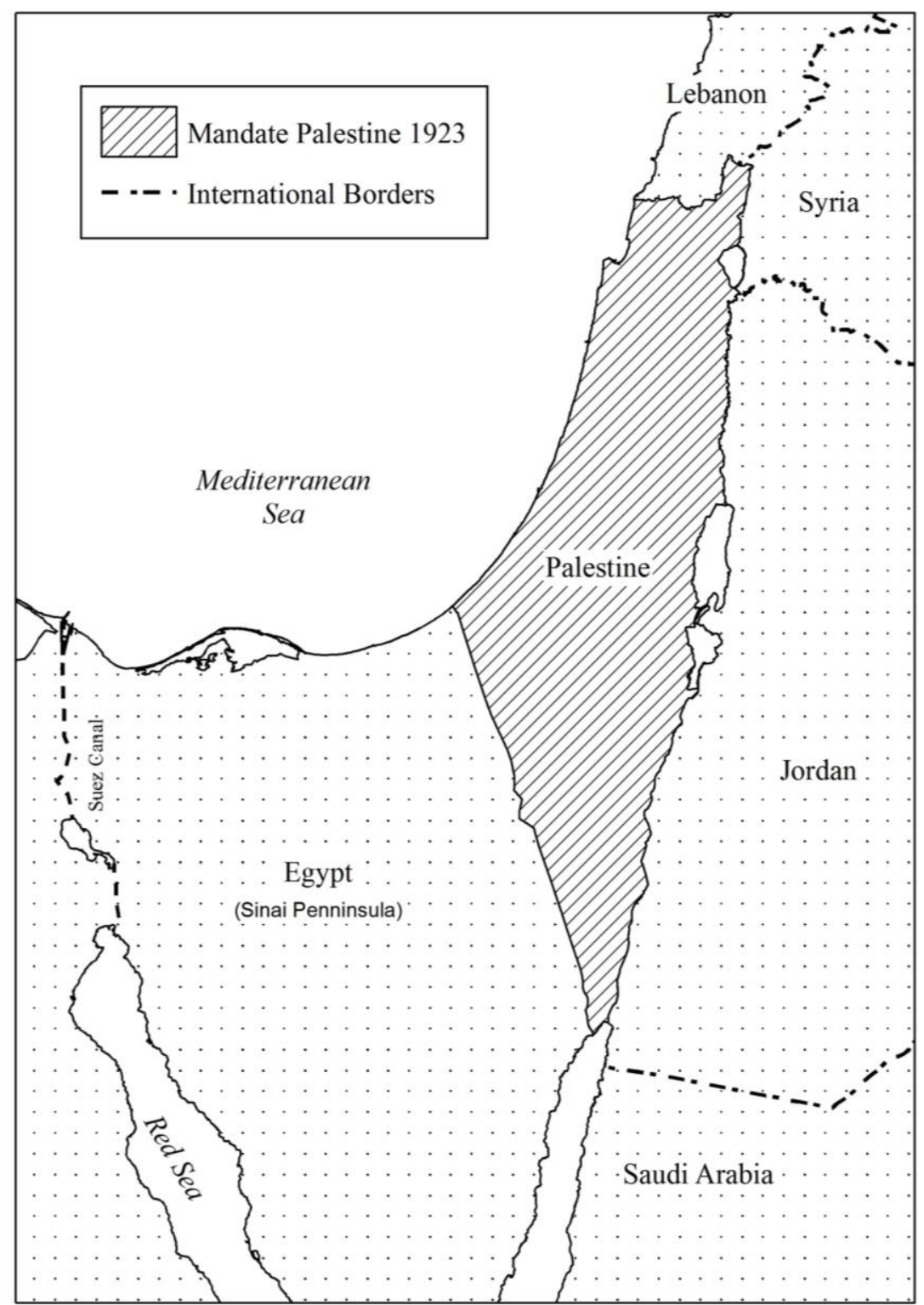

Map of Palestine under the British mandate in the early 1920's (adapted by the author from OpenStreetMap) 


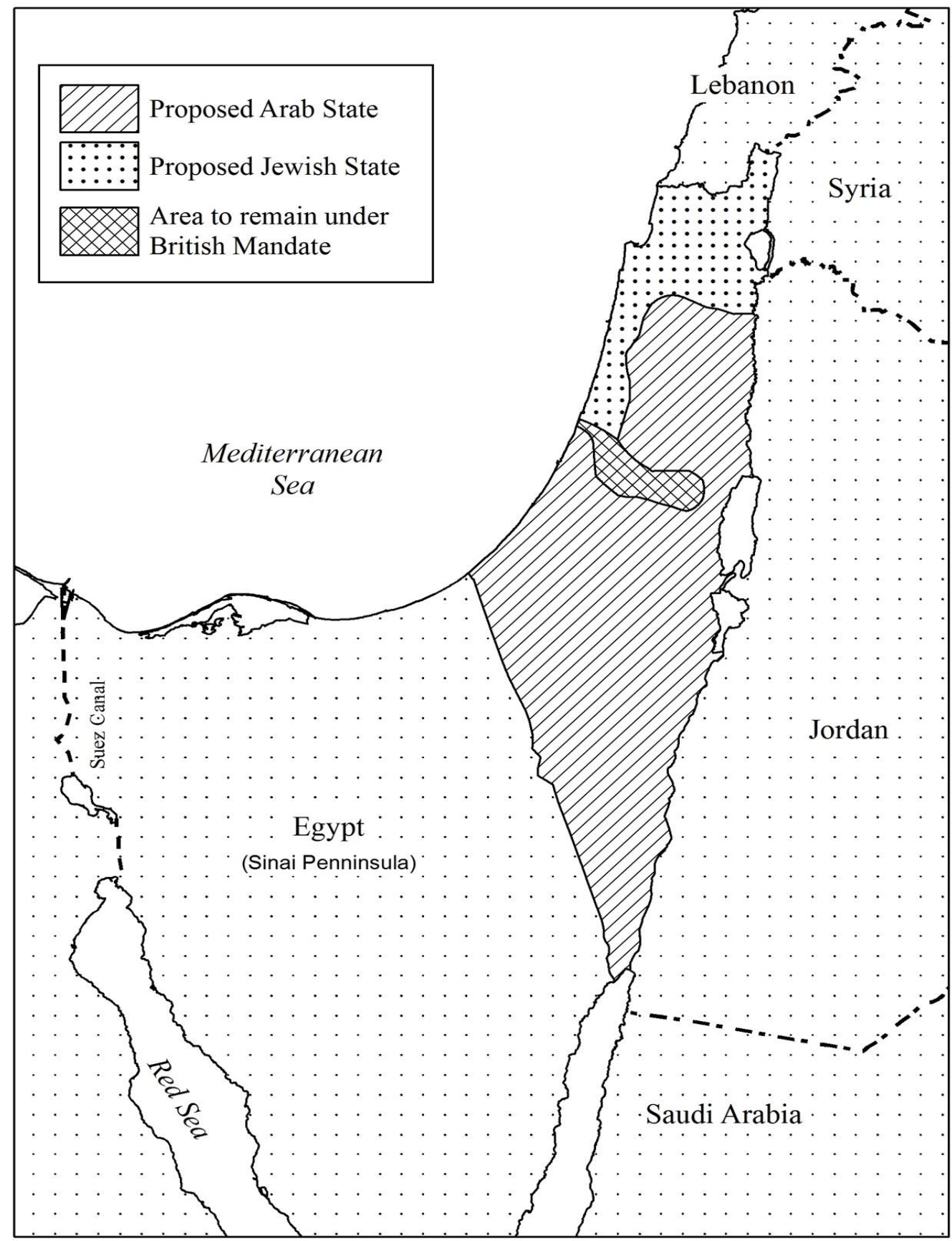

Map of Palestine according to the Peel Commission in 1937 (adapted by the author from OpenStreetMap). 


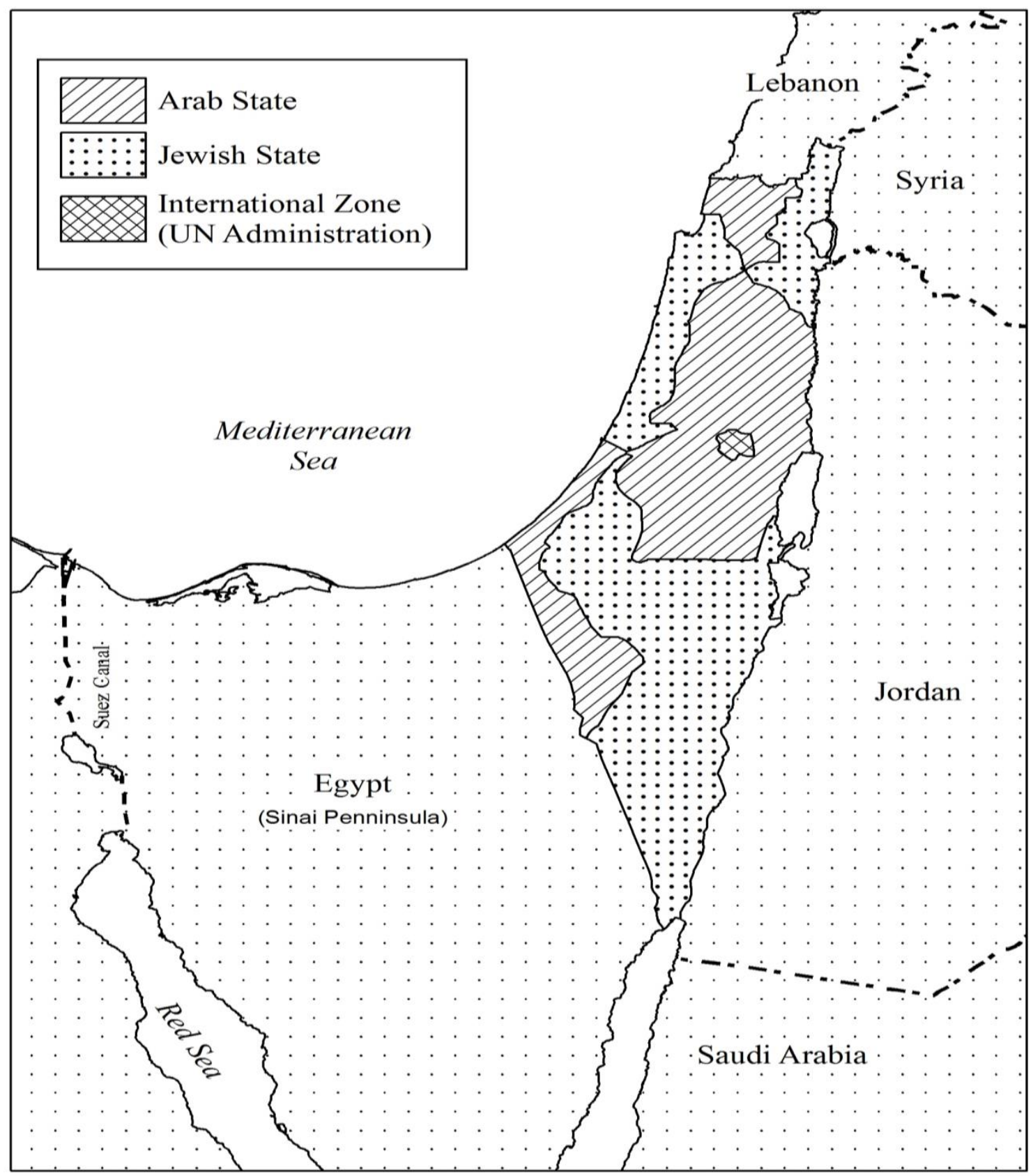

Map of Palestine according to the United Nations Partition Plan in 1947 (adapted by the author from OpenStreetMap). 


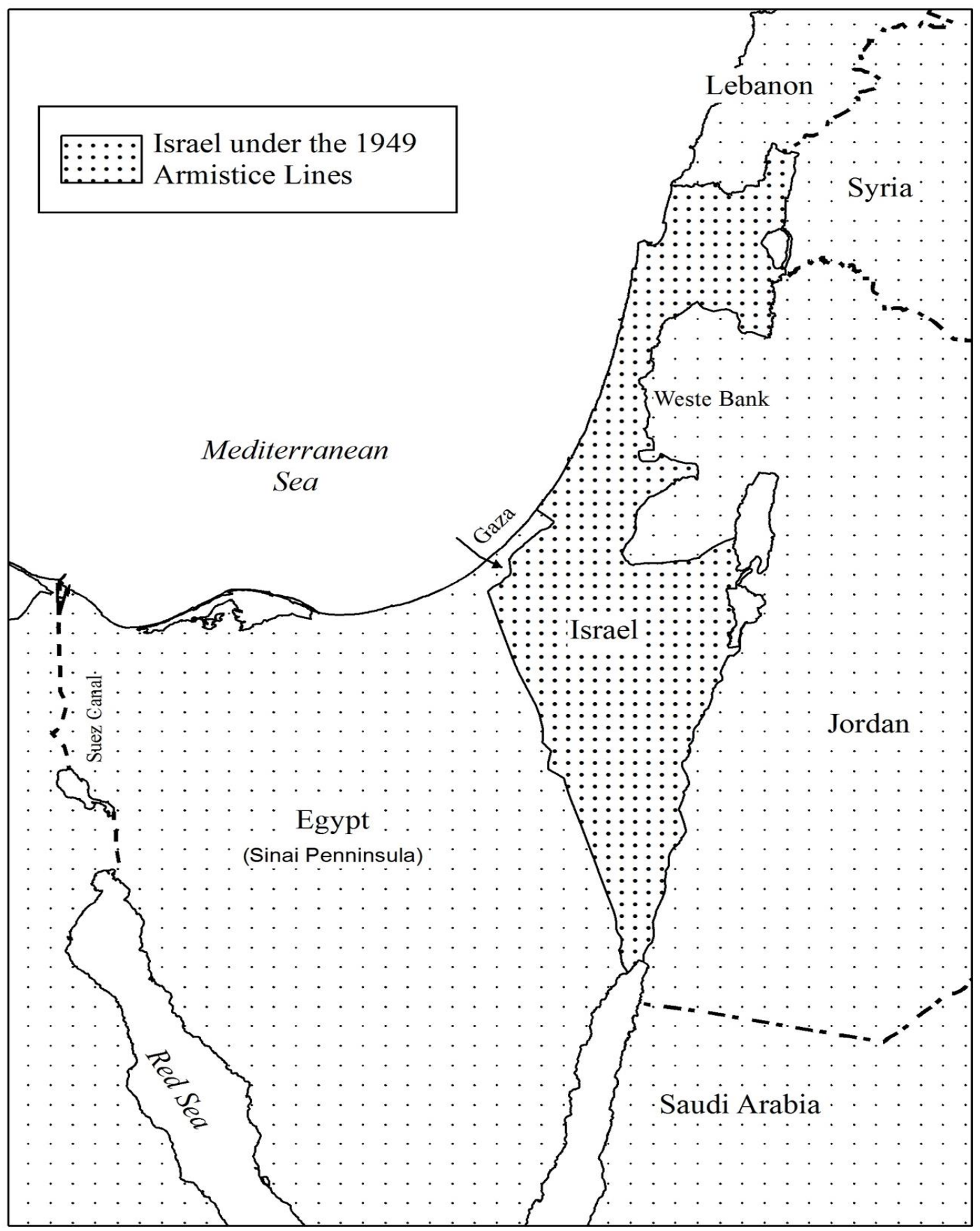

Map of Palestine after the 1948 war reflecting the armistice boundaries in 1949 (adapted by the author from OpenStreetMap). 


\section{Works Cited:}

Benvenisti, M. Sacred Landscape: The buried history of the Holy Land since 1948. Berkeley: University of California Press, 2000.

Biger, Gideon. The Boundaries of Modern Palestine, 1840-1947. London and New York: Routledge, 2004.

Crampton, Jeremy and Krygier, John. An Introduction to Critical Cartography. ACME: An International E-Journal for Critical Geographies, 4 (1), 11-33 2010.

Crampton, Jeremy. The Political Mapping of Cyberspace. Chicago: University of Chicago Press, 2004.

Edney, Matthew. Mapping an Empire: The Geographical Construction of British India. Chicago: University of Chicago Press, 1997.

Firth, Rhiannon. Critical Cartography (15 April 2015). The Occupied Times of London (27). Retrieved 16 February 2018.

"Critical Cartography as Anarchist Method? Utopian Extrapolation and Pedagogy” Interface: A journal by and for Social Movements (2014) 6:156-184.

Foucault, Michel. Power/Knowledge: Selected Interviews and Other Writings, 1972-197: New York: Pantheon, 1980.

Hanieh, Akram. The Camp David Papers. Journal of Palestine Studies (2001) 30:75-97.

Gavish, Dov. A Survey of Palestine under the British Mandate, 1920-1948. London:

Routledge, 2005.

Gramsci, Antonio. Selections from the Prison Notebooks. New York: International Publishers Co. 1971.

Gregory, Derek. Geographical Imaginations. Oxford: Wiley-Blackwell, 1998.

Kanafani Ghassan. Palestine's Children: Returning to Haifa and Other Stories, Ed/Trans. Barbara Harlow and Karen E Riley. Boulder, Colorado: Lynne Rienner Publishers Inc., 2000. (PP. 149-196).

Krygier, John . Critical Cartography. International Encyclopedia of Human Geography, 2nd edition, Volume 3 (25-29) 2019 
Lefebvre, Henri. The Production of Space. Oxford: Wiley-Blackwell, 1991.

Long, Burke O. Imagining the Holy Land: Maps, Models, and Fantasy Travels. Bloomington: Indiana University Press, 2002.

Massey, Doreen. For Space. London: Sage, 2005.

Matar, Nabil. "Renaissance Cartography and the Question of Palestine." Pp. 139151 in The Landscape of Palestine: Equivocal Poetry, edited by I. Abu-Lughod, R. Heacock, and K. Nashef. Ramallah: Birzeit University Press, 1999. Pp.139-151.

McTague Jr., John J. Anglo-French Negotiations over the Boundaries of Palestine, 1919-1920. Journal of Palestine Studies (1982) 11:100-112.

Moscrop, John James. Measuring Jerusalem: The Palestine Exploration Fund and British Interests in the Holy Land. London: Leicester University Press, 2000.

Pickles, John. A History of Spaces: Cartographic Reason, Mapping and the GeoCoded World: Oxford: Routledge, 2003.

Quiquivix, Linda Elizabeth. The Political Palestine (Diss). Chapel Hill: University of North Carolina, 2012.

Robinson, Edward and Eli Smith. Biblical researches in Palestine, and the adjacent regions. Boston: Crocker and Brewster, 1856. P.10.

Sack, Robert David. Human territoriality: its theory and history. New York: Cambridge University Press, 1986.

Said, Edward. Facts, facts, and more facts. in Peace and Its Discontents: Essays on Palestine in the Middle East Peace Process. New York: Vintage, 1996. PP. 26-31.

Silberman, Neil Asher. Digging for God and Country: Exploration, archeology, and the secret struggle for the Holy Land, 1799-1917. New York: Random House, 1982.

Sparke, Matthew. A Map that Roared and an Original Atlas: Canada, Cartography, and the Narration of Nation. Annals of the Association of American Geographers (1998) 88: 463-495.

Wood, Denis. The Power of Maps: New York: The Guilford Press, 1992. 


\section{فلسطين في الجغرافيا و الرواية: مقاربة بينية

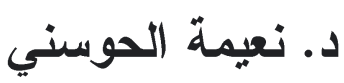 \\ رئيس قسم الجغرافيا والاستدامة الحضرية \\ جامعة الإمارات العربية المتحدة والاسية}

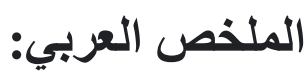

باستخدام الدراسات النقدية المعاصرة لعلم الخرائط كأساس نظري ومدخل

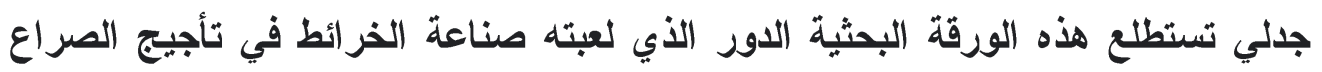

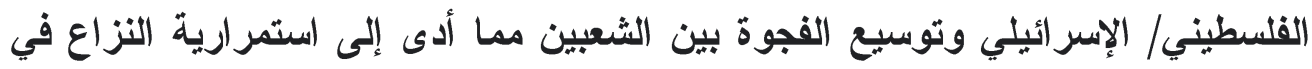
الثرق الأوسط. علاوة على علم الخرائط تستند الاراسة على مرويات سياسية وتاريخية

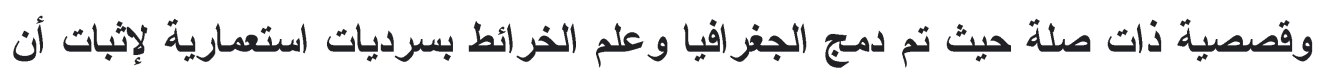

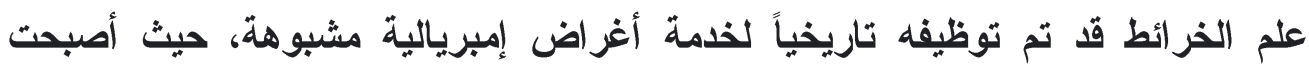
فلسطين نهباً للفزاة وتحولت إلى منطقة إقليمية مباحة للسيطرة والهيمنة الهينة الاستعمارية.

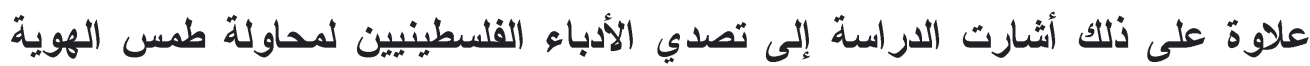

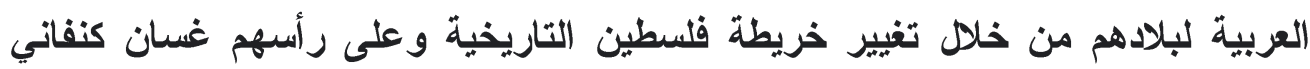

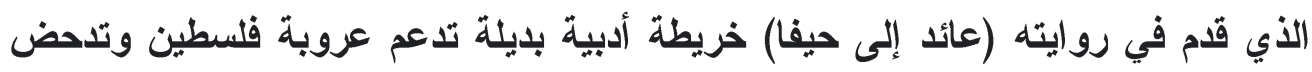
الخرائط الاستعمارية وتكفل حق الوجود والعيش المشترك لكل من العرب واليهود في فلسطين. الكلمات المفتاحية: فلسطين ، الجغرافيا ، النزاع، الخرائط ، الغزاة. 